\title{
IMPACT OF MIXED LACTIC ACID BACTERIAL (LAB) CULTURE ON FLAVORING PROFILE AND QUALITY ATTRIBUTES OF SPRING WHEAT SOURDOUGH BREAD
}

\author{
Zaib-Un-Nisa $^{1}{ }^{*}$, Salim-Ur-Rehman ${ }^{1}$, Nuzhat Huma ${ }^{1}$ and Muhammad Shahid ${ }^{2}$ \\ ${ }^{1}$ National Institute of Food Science and Technology, University of Agriculture, Faisalabad, Pakistan; \\ ${ }^{2}$ Department of Chemistry, University of Agriculture, Faisalabad, Pakistan. \\ "Corresponding author's e-mail: zee_nisa@ hotmail.com
}

\begin{abstract}
Wheat is a main ingredient of the bread, so the suitability of mixed culture of Lb. casei, Lb. brevis and Candida humilis was determined for different spring wheat cultivars for the preparation of sourdough bread. Four spring wheat cultivars such as Lasani-2008, Millat-2011, Punjab-2011 and AARI-2011 were analyzed for chemical composition, physical and farinographic parameters. The cultivars were found significantly $(\mathrm{P}<0.05)$ different in physicochemical and farinographic parameters. Millat-2011 exhibited the highest scores for all these parameters. Breads prepared from these cultivars were analyzed for $\mathrm{pH}$, titratable acidity, organic acids, and volatile compounds. The sourdough bread prepared was also subjected to analysis of essential amino acids and various sensory attributes. Sourdough bread produced from Millat-2011 had the highest sensory scores. Fermentation by LAB improved the flavoring compounds and amino acid profile of the sourdough bread as compared to yeast leavened bread. The value of lysine improved from $0.16 \mathrm{~g} / 100 \mathrm{~g}$ to $0.39 \mathrm{~g} / 100 \mathrm{~g}$. Ethanol; 1-propanol, 2-methyl; 1butanol; 2-methyl-1-butanol; 3-methyl ethyl acetate; acetaldehyde; acetic acid; 1-hexanol; benzaldehyde; hexanal; N-hexanal and propanal-2-methyl were found in sourdough bread.
\end{abstract}

Keywords: Flavoring compounds, functional breads, sourdough, fermentation, microbes.

\section{INTRODUCTION}

Cereals in general and wheat, in particular, are principle foods around the world that provide more nutrients than any other single food source. Wheat is the main staple food of the country's population. It contributes $2.2 \%$ to GDP and $10.1 \%$ to the value added in agriculture (GOP, 2013). Pakistani wheat cultivars on an average contain 8.38-9.67\% moisture, $9.15-10.27 \%$ crude protein, $1.15-2.55 \%$ crude fat, $1.72-1.85 \%$ crude fibre and $1.44-2.10 \%$ ash (Khan and Zeb, 2007). In Pakistan, about $70 \%$ of the total wheat produced is utilized to produce unleavened flat bread and other bakery stuff like cakes, cookies, breads and pastries etc. (Rehman et al., 2014).

In recent times, emphasis is given on developing the nutritious bread with more protein and dietary fibre content and low glycemic index. In this regard, sourdough fermented bread is a suitable alternate of yeast leavened bread. It is health promoting and is associated with a decrease risk for certain diseases. It has an important role in improving the quality attributes of bread (Poutanen et al., 2009).

The sourdough is a natural process in which flour and water is mixed and fermented with the help of microbes (bacteria and yeast) that are obtained either from starter culture or previous sourdough. As a result, Hetero fermentative lactic acid bacteria produce lactic and acetic acid resulting in sour taste of the bread. Sourdough fermentation has many advantages over the straight dough method that includes prolonged shelf life by delaying staling and improved nutritional status. It also improves various sensory characteristics and inhibits the growth of spoilage bacteria and mold. Moreover, it also improves bioavailability of minerals and reduces the glucose and insulin responses in human. The increase in production of folate (vitamin B) and thiamin and decrease in vitamin $\mathrm{E}$ (tocopherol and tocotrienol) content is also associated with the fermentation of sourdough (Banu et al., 2011). During fermentation of dough, $\mathrm{pH}$ dependent proteolysis takes place and produces significant amount of peptides and amino acids in the sourdough. Consequently, increased concentration of peptides and amino acids in the product may regulate the glucose metabolism in the body (Nielsen et al., 2007).

The dough prepared from lactic acid bacteria (LAB) is natural, additive free and is used for leavening purposes in various bakery products. Mostly, Lb. brevis, Lb. plantarum and $L b$. sanfranciscensis have been isolated and identified in sourdoughs. Beside this, numerous yeast species, Sacchromyces cerevisiae and Candida humilis are also used in the fermentation of sourdoughs. Homo-fermentative species play a key role in the production of various flavoring compounds and organic acids. These species are unable to produce $\mathrm{CO}_{2}$. Homo fermentative $\mathrm{LAB}$ have the major function in the production of lactic acid while the production of acetic acid is mainly associated with hetk8ro-fermentative 
lactic acid bacteria resulted in the pleasant odor and sour taste of the breads. The sourdough bread is richer in aroma and flavor than yeast leavened bread (Rehman and Awan, 2011). In the present study, Lb. casei and Lb. brevis which are homo and heterofermentative in nature were the part of mixed culture, respectively and yeast, Candida humilis which is synergistic in action had also been used.

Bread and other wheat products are the essential part of daily food intake; so such food items should be safe, healthy and wholesome. Flour processing like milling, refining, bleaching, enriching, and fortification to flour and baked breads cause medical workers and food scientists to question their safety and nutritional quality. So the emphasis should be given on developing the food products especially bread which is not only nutritious but also have the positive effect on the human health. In Pakistan, straight dough development method is generally used for the production of bread which results in inferior quality, flavor and lesser health benefits. In this regard, sourdough fermented bread is a suitable choice to obtain improved nutritional profile and longer shelf stability. So this project is designed to improve the nutritional value, functional properties as well as sensory attributes of the bread by using the sourdough development method.

\section{MATERIALS AND METHODS}

Wheat cultivars were purchased from Ayub Agriculture Research Institute, Faisalabad. Analytical grade chemicals were procured from Merck (KGaA, 64271, Darmstadt, Germany).

Chemical analysis: Wheat samples were analyzed for proximate composition including moisture content, crude fat, crude protein, ash content, crude fibre and NFE (AACC, 2006).

Thousand kernel weight and test weight: Thousand kernel weight and test weight of samples were determined by applying methods as described in AACC (2006). Wheat samples were milled after tempering and straight grade flour (72\% extraction rate) (SGF) was prepared by mixing two fractions of flour (AACC, 2006). Dry and wet gluten content and falling numbers of flours were determined by applying the methods 38-10 and 56-81, respectively. Pelshenke and Sedimentation values were determined by following the procedures outlined in method 56-61-3 and 56-50, respectively (AACC, 2006).

Farinographic characteristics: Brabender Farinograph (C.W. Brabender, Duisburg, Germany) was used to determine the Rheological characteristics of flour samples by following the method No. 54-21 (AACC, 2006). Dough rheological characters such as water absorption (WA), dough development time (DDT), dough stability (DS), softening of dough (SOD) and tolerance index (TI) were interpreted through farinogram.
Preparation of sourdough bread: For making sourdough bread, a sponge was prepared from flour (200 g), water (200 $\mathrm{mL}$ ) and starter culture was added to give $10^{8} \mathrm{CFU} / \mathrm{g}$ of dough bacterial count. Freeze dried culture namely LV-4 was procured from Lallemand Baking Solutions, Montreal, Canada. LV-4 culture containing Lactobacillus brevis and Lb. casei and Candida humilis was used. This was mixed thoroughly and incubated at $30^{\circ} \mathrm{C}$ for $20 \mathrm{~h}$. The sourdough was prepared by mixing $200 \mathrm{~g}$ flour, $120 \mathrm{~mL}$ water and $70 \mathrm{~g}$ fermented sponge, incubated for $24 \mathrm{~h}$ at $30^{\circ} \mathrm{C}$. Then the bread was prepared and baked at $215^{\circ} \mathrm{C}$ for $25 \mathrm{~min}$.

pH and titratable acidity: $\mathrm{pH}$ and total titratable acidity (TTA) of sourdough breads were determined by using $\mathrm{pH}$ meter (Inolab WTW Series 720) (Lefebvre et al., 2002).

Organic acids: Lactic acid and acetic acid contents of sourdough bread were determined using High Performance Liquid Chromatography (HPLC) according to the method as described by Vernockchi et al. (2004). Saq. HPLC (Model 1050, Hewlett-Packard, Waldbronn Germany) equipped with a Bio-Rad Aminex HPX-87H column $(300 \times 7.8 \mathrm{~mm})$ was used. For HPLC analysis, sample was prepared by mixing 10 $\mathrm{g}$ of bread sample with $100 \mathrm{~mL}$ of $0.1 \mathrm{~N}$ sulfuric acid solution, the mixture was then homogenized by an Omni Mixer Homogenizer for $5 \mathrm{~min}$ (Omni International, Warrengton, VA) and filtered through a $0.22 \mathrm{~mm}$ membrane filter. The prepared sample was analyzed according to the following conditions. Mobile phase, $0.08 \mathrm{M} \mathrm{H}_{2} \mathrm{SO}_{4}$; flow rate, $0.60 \mathrm{~mL} / \mathrm{min}$; temperature, $65^{\circ} \mathrm{C}$; $\mathrm{UV}$ detector $(210$ $\mathrm{nm})$.

Amino acid analysis: Samples of yeast leavened and sourdough bread were subjected to determination of amino acids composition using an amino acid analyzer according to the method of Dabbour and Takuri (2000).

Volatile compounds: Volatile compounds of wheat sourdough bread and yeast leavened bread were determined by GC-FID (Kam et al., 2011). For the extraction of volatile compound, a $70 \mathrm{~g}$ sample with $20 \% \mathrm{w} / \mathrm{v}$ of sodium chloride was centrifuged at $4500 \mathrm{rpm}$ at $2^{\circ} \mathrm{C}$ for $5 \mathrm{~min}$. $25 \mathrm{~mL}$ of the supernatant was mixed with the ethyl acetate in a proportion of $1: 1$ and stirred for $40 \mathrm{~min}$. Then, the mixture was centrifuged again at $2000 \mathrm{rpm}$ at $2^{\circ} \mathrm{C}$ for $5 \mathrm{~min}$. The organic phase collected in a round-bottom flask was concentrated up to $1.5 \mathrm{~mL}$ at $40^{\circ} \mathrm{C}$ by using a vacuum rotary evaporator (Buchi, Switzerland).

The extracted sample was analyzed and identified with GCFID (GC-17A, Shimadzu). A $30 \mathrm{~m} \times 0.25 \mathrm{~mm}$ (ID) DBWAX capillary column, with $0.25 \mu \mathrm{m}$ film thickness, was used. The sample $(1 \mu \mathrm{L})$ was injected in split mode (1:50) and the injection temperature was $270^{\circ} \mathrm{C}$. Nitrogen was used as carrier gas at a constant flow of $30 \mathrm{~mL} / \mathrm{min}$. The oven temperature was programmed as $80^{\circ} \mathrm{C}$ for $1 \mathrm{~min}$, increased to $120^{\circ} \mathrm{C}$ at $4^{\circ} \mathrm{C} / \mathrm{min}$, and then increased to $240^{\circ} \mathrm{C}$ at $15^{\circ} \mathrm{C} / \mathrm{min}$ rate. The data acquisition was performed with CSW32-Chromatography Station, Data Apex, Ltd, 2001. 
Sensory evaluation of sourdough bread: Sourdough breads were evaluated for sensory characteristics at ambient temperature by panel of judges using 9-point Hedonic Scale (Land and Shepherd, 1988).

Statistical Analysis: The data collected was subjected to the statistical analysis using Minitab (V.15.1, Minitab Inc., PA 16801-3008, USA). Duncan's Multiple Range test was applied to estimate the level of significance (Steel et al., 1997).

\section{RESULTS AND DISCUSSION}

Thousand kernel weight and test weight: The mean values for thousand kernel weight and test weight varied from 37.26-44.23 g and 73.29-81.53 Kg.hL ${ }^{-1}$, respectively as shown in Table 1. Results showed the significant $(\mathrm{P}<0.01)$ differences among wheat cultivars regarding the thousand kernel weight and test weight. The results are supported by Khan and Shewry (2009) who observed that the test weight and thousand kernel weights varied from 66.47-76.90 Kg.hL ${ }^{-1}$ and 25.98-40 g, respectively. In another study, Pakistani wheat cultivar showed the $41 \mathrm{~g} 1000$ kernel weight and $79 \mathrm{Kg} \cdot \mathrm{hL}^{-1}$ test weight (Pasha et al., 2013).

Table 1.Physical characteristics of various spring wheat cultivars.

\begin{tabular}{lcc}
\hline Cultivars & $\begin{array}{c}\text { Test weight } \\
\left(\text { Kg.hL }^{-1}\right)\end{array}$ & $\begin{array}{c}\text { Thousand kernel } \\
\text { weight }(\mathbf{g})\end{array}$ \\
\hline AARI-2011 & $77.05 \pm 0.45 \mathrm{c}$ & $42.38 \pm 0.32 \mathrm{~b}$ \\
Millat-2011 & $81.53 \pm 0.34 \mathrm{a}$ & $44.43 \pm 0.29 \mathrm{a}$ \\
Punjab-2011 & $79.68 \pm 0.30 \mathrm{~b}$ & $37.26 \pm 0.37 \mathrm{~d}$ \\
Lasani-2008 & $73.29 \pm 0.46 \mathrm{~d}$ & $39.27 \pm 0.37 \mathrm{c}$ \\
\hline
\end{tabular}

Means bearing different letters in each column differ significantly $(\mathrm{P}<0.01)$.
Dry and wet gluten, falling number, SDS-sedimentation value and Pelshenke value: Results regarding dry and wet gluten, falling number, SDS-sedimentation value and Pelshenke value of spring wheat cultivars are presented in Table 2. The mean values for falling number, wet and dry gluten, SDS-sedimentation value and Peleshenke value of cultivars varied between 463.00-518.67 sec, 20.92-28.99\%, $6.61-9.90 \%, 23.28-36.35 \mathrm{~mL}$ and $185.00-211.00 \mathrm{~min}$, respectively. Various Pakistani spring wheat cultivars contain dry and wet gluten content in the range of 8.88$10.09 \%$ and $27.60-35.15 \%$, respectively (Anjum and Walker, 2000). Pakistani wheat cultivars were found low in amylase activity as indicated by their falling number values (Pasha et al., 2007). The results for SDS-sedimentation values were also found in close agreement with the findings of Pederson et al. (2004) who concluded that the SDSsedimentation values varied between 17-32 mL. Pelshenke values below 60, 60-120 and above 120 min depicts soft, medium strong and strong gluten, respectively. The results of current study revealed that Pelshenke values for all wheat cultivars were $>120$ min depicting the strong gluten quality.

Proximate analysis: The mean values for moisture, crude fat, crude fibre, crude protein, crude ash and nitrogen free extract (NFE) contents are presented in Table 3 and ranged between $10.91-12.93 \%, 1.28-1.44 \%, 0.32-0.40 \%$, $11.51-$ $14.70 \%, 0.44-0.57 \%$ and $83.1-86.25 \%$, respectively. The statistical analysis revealed that moisture, crude protein, crude fat and NFE contents of flour differed highly significantly $(\mathrm{P}<0.01)$ while crude fibre and total ash contents showed the significant $(\mathrm{P}<0.05)$ results. The results of the present study was found in agreement with the earlier finding of Ahmed (2001) who observed crude protein, crude fibre, ash, crude fat, moisture and NFE content in the range of $10.15-13.76 \%, 1.32-1.85 \%, 2.31-2.99,1.96-2.52,9.38-$

Table 2. Falling number, dry and wet gluten, SDS-Sedimentation value and Pelshenke value of various spring wheat cultivars.

\begin{tabular}{lccccc}
\hline Cultivars & $\begin{array}{c}\text { Falling Number } \\
(\mathbf{s e c})\end{array}$ & $\begin{array}{c}\text { Wet Gluten } \\
(\boldsymbol{\%})\end{array}$ & $\begin{array}{c}\text { Dry Gluten } \\
(\boldsymbol{\%})\end{array}$ & $\begin{array}{c}\text { SDS-Sedimentation } \\
\text { Value }(\mathbf{m L})\end{array}$ & $\begin{array}{c}\text { Pelshenke Value } \\
(\mathbf{m i n})\end{array}$ \\
\hline AARI-2011 & $463.00 \pm 4.58 \mathrm{c}$ & $24.34 \pm 0.37 \mathrm{c}$ & $7.41 \pm 0.08 \mathrm{c}$ & $23.28 \pm 0.31 \mathrm{~d}$ & $203.00 \pm 1.15 \mathrm{~b}$ \\
Millat-2011 & $518.67 \pm 2.60 \mathrm{a}$ & $28.99 \pm 0.37 \mathrm{a}$ & $9.09 \pm 0.17 \mathrm{a}$ & $36.35 \pm 0.23 \mathrm{a}$ & $211.00 \pm 1.15 \mathrm{a}$ \\
Punjab-2011 & $511.67 \pm 2.40 \mathrm{a}$ & $20.92 \pm 0.23 \mathrm{~d}$ & $6.61 \pm 0.15 \mathrm{~d}$ & $29.327 \pm .445 \mathrm{c}$ & $185.00 \pm 1.15 \mathrm{~d}$ \\
Lasani-2008 & $496.67 \pm 3.53 \mathrm{~b}$ & $26.31 \pm 0.29 \mathrm{~b}$ & $8.56 \pm 0.12 \mathrm{~b}$ & $31.400 \pm .444 \mathrm{~b}$ & $192.33 \pm 1.45 \mathrm{c}$ \\
\hline
\end{tabular}

Means bearing different letters in each column differ significantly $(\mathrm{P}<0.05)$.

Table 3. Proximate composition of various spring wheat cultivars.

\begin{tabular}{lcccccc}
\hline Cultivar & $\begin{array}{c}\text { Moisture } \\
(\boldsymbol{\%})\end{array}$ & $\begin{array}{c}\text { Crude fat } \\
(\boldsymbol{\%})\end{array}$ & $\begin{array}{c}\text { Crude fibre } \\
(\boldsymbol{\%})\end{array}$ & $\begin{array}{c}\text { Crude Protein } \\
(\boldsymbol{\%})\end{array}$ & $\begin{array}{c}\text { Ash } \\
(\boldsymbol{\%})\end{array}$ & $\begin{array}{c}\text { NFE } \\
(\boldsymbol{\%})\end{array}$ \\
\hline AARI-2011 & $12.16 \pm 0.05 \mathrm{~b}$ & $1.28 \pm 0.006 \mathrm{~b}$ & $0.40 \pm 0.006 \mathrm{a}$ & $11.51 \pm 0.14 \mathrm{~d}$ & $0.57 \pm 0.003 \mathrm{a}$ & $86.25 \pm 0.13 \mathrm{a}$ \\
Millat-2011 & $10.91 \pm 0.04 \mathrm{~d}$ & $1.44 \pm 0.025 \mathrm{a}$ & $0.32 \pm 0.006 \mathrm{c}$ & $14.70 \pm 0.09 \mathrm{a}$ & $0.44 \pm 0.012 \mathrm{~d}$ & $83.10 \pm 0.14 \mathrm{~b}$ \\
Punjab-2011 & $12.93 \pm 0.03 \mathrm{a}$ & $1.32 \pm 0.009 \mathrm{~b}$ & $0.36 \pm 0.007 \mathrm{~b}$ & $13.52 \pm 0.16 \mathrm{c}$ & $0.52 \pm 0.009 \mathrm{~b}$ & $84.28 \pm 0.13 \mathrm{c}$ \\
Lasani-2008 & $11.67 \pm 0.14 \mathrm{c}$ & $1.39 \pm 0.009 \mathrm{a}$ & $0.34 \pm 0.006 \mathrm{~b}$ & $14.07 \pm 0.03 \mathrm{~b}$ & $0.47 \pm 0.012 \mathrm{c}$ & $83.73 \pm 0.12 \mathrm{~b}$ \\
\hline
\end{tabular}

Means bearing different letters in each column differ significantly $(\mathrm{P}<0.05)$. 
$10.43 \%$ and $78.71-85.37$, respectively among various wheat cultivars.

Farinographic properties: The mean values for farinographic parameters revealed that significant differences $(\mathrm{P}<0.01)$ were observed among various spring wheat cultivars (Table 4). The means values regarding WA, SOD, DDT, DS, MIT, AT, DT ranged between 54.7360.37\%, 45.33-141.00 BU, 2.50-6.80 min, 15.64-22.10 min, 22-49 BU, 0.90-1.37 min and 16.59-23.33 min. Millat-2011 was found best for the preparation of sourdough bread, as it showed the better water absorption and dough development time. The result of the present studies were closely related to the findings of Safdar et al. (2012) who found the variation for all these parameters between 54.96-58.15\%, 33.67112.33 BU, 2.35-4.06 min, 39.67-106.67 BU, respectively. Variations in WA and AT depend upon protein quality and damaged starch content (Anjum and Walker, 1991).

pH and titratable acidity: The mean values presented in Table 5 indicated that $\mathrm{pH}$ and TTA of sourdough breads varied from 4.70 to 5.17 and 3.47 to $4.60 \%$ among the treatments, respectively. Relatively lower $\mathrm{pH}$ value (4.7) was observed for sourdough bread prepared from Millat2011 as compared to control (5.17). However, higher TTA $4.60 \mathrm{~mL}$ was found in Millat-2011 than control $(3.47 \mathrm{~mL})$. Results are comparable to the findings of Sandra et al. (2012) who reported that $\mathrm{pH}$ and TTA of various sourdough and yeast bread ranged between 4.5-5.7 and 2.0-5.4 mL, respectively. Sourdough fermentation process breaks down the carbohydrates to form the lactic acid resulting in acidity and lowering of $\mathrm{pH}$ of bread (Ostman, 2003).
Lactic acid and acetic acid content: The mean values for lactic acid and acetic acid contents (Table 5) of sourdough breads showed that various treatments for sourdough bread produced lactic acid and acetic acid content in the range of 0.013-0.46 g/100 g and 0.001-0.17 g/100 g, respectively. Control has the lowest value for both acids. Chiefly, lactic acid and acetic acids are produced during the sourdough fermentation. The results for lactic acid content produced in sourdoughs may be supported by the findings of Robert et al. (2005) who found lactic acid production in the range of $0.30-0.55 \mathrm{~g} / 100 \mathrm{~g}$ and concluded that the rheological characteristics, acidification and metabolic activity of the wheat sourdough bread were affected by using freeze dried starters. With regards to acetic acid, the results of current study are in conformity with the earlier findings that acetic acid content of the wheat sourdoughs lies in the range of 0.003-0.25 g/100 $\mathrm{g}$ depending upon the factors such as flour type, starter and fermentation conditions. Sourdough fermentation process breaks down the carbohydrates to form the lactic acid resulting in the lowering of sugar level in the dough. The conversion of sugars to lactic acid in sourdough bread can aid to keep blood glucose level in line, helping to guard against diabetes. The lactic acid produced by the sourdough fermentation has also the ability to modify the macromolecules as it reduces the starch digestability (Ostman, 2003) whereas, acetic and propionic acids delay the gastric emptying rate (Liljeberg et al., 1995). The present study suggested that sourdough bread prepared from the freeze dried starter culture produced more organic acids than the yeast which improve the flavor and aroma of the bread.

Table 4. Farinographic characteristics of straight grade flour (SGF) of various spring wheat cultivars.

\begin{tabular}{lrrrr}
\hline Parameters & AARI-2011 & Millat-2011 & Punjab-2011 & Lasani-2008 \\
\hline WA (\%) & $54.73 \pm 0.07 \mathrm{~d}$ & $60.37 \pm 0.15 \mathrm{a}$ & $56.23 \pm 0.09 \mathrm{c}$ & $57.60 \pm 0.12 \mathrm{~b}$ \\
SOD (BU) & $141.00 \pm 1.15 \mathrm{a}$ & $54.33 \pm 2.33 \mathrm{c}$ & $84.00 \pm 1.53 \mathrm{~b}$ & $45.33 \pm 1.86 \mathrm{~d}$ \\
DDT (min) & $5.96 \pm 0.03 \mathrm{c}$ & $6.80 \pm 0.06 \mathrm{a}$ & $6.34 \pm 0.07 \mathrm{~b}$ & $2.50 \pm 0.12 \mathrm{~d}$ \\
DS (min) & $17.70 \pm 0.06 \mathrm{~b}$ & $22.10 \pm 0.06 \mathrm{a}$ & $15.98 \pm 0.01 \mathrm{c}$ & $15.64 \pm 0.06 \mathrm{~d}$ \\
MIT (BU) & $49.00 \pm 0.58 \mathrm{a}$ & $29.00 \pm 1.73 \mathrm{c}$ & $38.00 \pm 0.58 \mathrm{~b}$ & $22.00 \pm 1.15 \mathrm{~d}$ \\
AT (min) & $0.93 \pm 0.04 \mathrm{~b}$ & $1.37 \pm 0.03 \mathrm{a}$ & $1.33 \pm 0.03 \mathrm{a}$ & $0.90 \pm 0.06 \mathrm{~b}$ \\
DT (min) & $18.47 \pm 0.15 \mathrm{~b}$ & $23.33 \pm 0.12 \mathrm{a}$ & $17.40 \pm 0.06 \mathrm{c}$ & $16.59 \pm 0.06 \mathrm{~d}$ \\
\hline
\end{tabular}

Means bearing different letters in each column differ significantly $(\mathrm{P}<0.01)$.

$\mathrm{WA}=$ Water absorption, $\mathrm{SOD}=$ Softening of dough, DDT $=$ Dough development time, $\mathrm{DS}=$ Dough stability, MIT $=$ Mixing tolerance index, AT= Arrival time, DT= Departure time.

Table 5. pH, titrable acidity and organic acid contents of sourdough bread.

\begin{tabular}{lcccc}
\hline Cultivars & $\mathbf{p H}$ & $\begin{array}{c}\text { Titratable acidity } \\
(\mathbf{m L ~ 0 . 1 N ~ N a O H})\end{array}$ & $\begin{array}{c}\text { Lactic acid } \\
(\mathbf{g} / \mathbf{1 0 0 g})\end{array}$ & $\begin{array}{c}\text { Acetic acid } \\
(\mathbf{g} / \mathbf{1 0 0 g})\end{array}$ \\
\hline AARI-2011 & $4.90 \pm 0.06 \mathrm{~b}$ & $4.00 \pm 0.21 \mathrm{c}$ & $0.41 \pm 0.012 \mathrm{a}$ & $0.05 \pm 0.012 \mathrm{c}$ \\
Millat-2011 & $4.70 \pm 0.06 \mathrm{c}$ & $4.60 \pm 0.12 \mathrm{a}$ & $0.46 \pm 0.018 \mathrm{a}$ & $0.17 \pm 0.015 \mathrm{a}$ \\
Punjab-2011 & $4.87 \pm 0.03 \mathrm{~b}$ & $4.13 \pm 0.19 \mathrm{bc}$ & $0.37 \pm 0.012 \mathrm{~b}$ & $0.14 \pm 0.006 \mathrm{~b}$ \\
Lasani-2008 & $4.77 \pm 0.03 \mathrm{bc}$ & $4.50 \pm 0.06 \mathrm{ab}$ & $0.33 \pm 0.012 \mathrm{~b}$ & $0.12 \pm 0.012 \mathrm{~b}$ \\
Control (Yeast) & $5.17 \pm 0.03 \mathrm{a}$ & $3.47 \pm 0.07 \mathrm{~d}$ & $0.013 \pm 0.002 \mathrm{c}$ & $0.001 \pm 0.00 \mathrm{~d}$ \\
\hline
\end{tabular}

Means bearing different letters in each column differ significantly $(\mathrm{P}<0.05)$. 
Hence, it is concluded that the LV-4 culture used in the current study produced more acids than that of control.

Amino acid profile of yeast leavened and sourdough bread: Amino acid composition of yeast leavened bread and sourdough wheat bread is presented in Table 6. It is depicted that the bread prepared from the mixed culture showed the higher amino acid content than the yeast leavened bread. Proteolysis during fermentation plays a key role to improve the essential amino acid profile. The value of lysine for yeast leavened bread and wheat sourdough bread was $0.16 \mathrm{~g} / 100 \mathrm{~g}$ and $0.39 \mathrm{~g} / 100 \mathrm{~g}$, respectively. Generally, dough fermentation with lactic acid bacteria improves the amino acid profile of sourdough bread (Thiele et al., 2002). The results are found similar with the findings of Barber and Baquean (1989) who reported that high proteolytic activity was found in sourdoughs as compared to yeast leavened bread and effective amino acid production was observed with sourdoughs fermented with lactic acid bacteria. The LAB starter culture in the present study produced significant amount of essential amino acids especially lysine which can help to improve the level of amino acids in the end product.

Table 6. Essential amino acid content of sourdough bread.

\begin{tabular}{lcc}
\hline & $\begin{array}{c}\text { Yeast leavened } \\
\text { bread }(\mathrm{g} / \mathbf{1 0 0 g})\end{array}$ & $\begin{array}{c}\text { Sourdough } \\
\text { bread }(\mathrm{g} / \mathbf{1 0 0 g})\end{array}$ \\
\hline Methionine & 0.04 & 0.14 \\
Lysine & 0.16 & 0.39 \\
Leucine & 0.32 & 0.78 \\
Iso leucine & 0.22 & 0.40 \\
Histidine & 0.09 & 0.22 \\
Valine & 0.16 & 0.47 \\
Threonine & 0.18 & 0.41 \\
\hline
\end{tabular}

Volatile compounds: Typical sourdough flavors are produced by the bacterial proteolysis during sourdough fermentation as compared to the yeast leavened breads (Hansen et al., 1989). In the present study, mixed culture of Lb. casei and Lb. brevis (homo and hetero fermentative bacteria, respectively) and yeast, Candida humilis had been used. Results regarding flavoring compounds of sourdough bread are presented in Table 7 which showed that ethanol; 1propanol,2-methyl; 1-butanol,2-methyl; 1-butanol,3-methyl; ethyl acetate and acetaldehyde were the main flavoring compounds of yeast fermented bread whereas, in addition to above, acetic acid; 1-hexanol; benzaldehyde; hexanal; Nhexanal and Propanal-2-methyl were present in breads fermented with mixed culture of Lb. brevis, Lb. casei and Candida humilis.

Flavoring compounds produced by $L b$. brevis was found more complete among others. However, in combination with yeast, both types of LAB can enhance the generation of volatile compounds of yeast (Gobbetti et al., 1995). It has been reported that generation of volatile compounds in sourdough bread may be improved by a mixture of homo and hetero fermentative lactic bacteria. The chief flavoring compounds of dough fermented with Candida humilis were 2-methyl-2-propanol and 3-methyl-1-butanol. Moreover, diacetyl may be produced by homofermentative LAB (Spicher et al., 1981). Aldehydes and ethyl acetate with some alcohols may be produced by heterofermentative LAB (Spicher et al., 1982).

Table 7. Comparison of volatile compounds of yeast leavened and sourdough bread.

\begin{tabular}{lcc}
\hline & $\begin{array}{c}\text { Yeast } \\
\text { bread }\end{array}$ & $\begin{array}{c}\text { Sourdough } \\
\text { fermented bread }\end{array}$ \\
\hline Alcohols & 125 & 181 \\
Ethanol & 31 & - \\
1-propanol, 2-methyl & 182 & 9 \\
1-butanol, 2-methyl & 89 & 71 \\
1-butanol, 3-methyl & 7 & 9 \\
1-hexanol & & \\
Esters & 11 & 22 \\
Ethyle acetate & 3 & 8 \\
Ethyl lactate & & \\
Acids & 9 & 16 \\
Acetic acid & - & 28 \\
Propionic acid & & \\
Carbonyls & 41 & 18 \\
Acetaldehyde & 2 & 5 \\
Benzaldehyde & - & 10 \\
Hexanal & - & 11 \\
N. hexanal & 4 & 6 \\
Propanal 2 methyl &
\end{tabular}

The amounts of volatile compounds are expressed in terms of Relative abundance $(\%)=$ (peak area of compound/peak area of standard) $\times 100$.

Table 8. Sensory characteristics of various spring wheat sourdough breads.

\begin{tabular}{llcccc}
\hline Parameters & Control & AARI-2011 & Millat-2011 & Punjab-2011 & Lasani-2008 \\
\hline Crust color & $8.00 \pm 0.29 \mathrm{ab}$ & $6.83 \pm 0.44 \mathrm{~b}$ & $8.50 \pm 0.50 \mathrm{a}$ & $7.63 \pm 0.19 \mathrm{ab}$ & $7.67 \pm 0.44 \mathrm{ab}$ \\
Crumb color & $7.83 \pm 0.44 \mathrm{ab}$ & $7.17 \pm 0.44 \mathrm{~b}$ & $8.83 \pm 0.17 \mathrm{a}$ & $7.33 \pm 0.33 \mathrm{~b}$ & $8.00 \pm 0.29 \mathrm{ab}$ \\
Flavor & $6.00 \pm 0.58 \mathrm{e}$ & $6.17 \pm 0.17 \mathrm{c}$ & $7.90 \pm 0.10 \mathrm{a}$ & $6.83 \pm 0.17 \mathrm{bc}$ & $7.33 \pm 0.33 \mathrm{ab}$ \\
Taste & $6.27 \pm 0.15 \mathrm{~d}$ & $7.00 \pm 0.00 \mathrm{c}$ & $8.97 \pm 0.26 \mathrm{a}$ & $8.00 \pm 0.29 \mathrm{~b}$ & $7.50 \pm 0.29 \mathrm{bc}$ \\
Texture & $8.67 \pm 0.17 \mathrm{a}$ & $6.57 \pm 0.35 \mathrm{de}$ & $8.50 \pm 0.29 \mathrm{ab}$ & $6.90 \pm 0.21 \mathrm{~cd}$ & $7.67 \pm 0.44 \mathrm{bc}$ \\
Over all acceptability & $7.3 \pm 0.18 \mathrm{c}$ & $6.74 \pm 0.13 \mathrm{~d}$ & $8.54 \pm 0.20 \mathrm{ab}$ & $7.33 \pm 0.31 \mathrm{~b}$ & $7.63 \pm 0.21 \mathrm{ab}$ \\
\hline
\end{tabular}

Means bearing different letters in each column differ significantly $(\mathrm{P}<0.05)$. 
Sensory evaluation: Comparison between wheat sourdough breads and yeast bread (control) showed the highly significant $(\mathrm{P}<0.01)$ differences among them for flavor, taste, texture and over all acceptability whereas the crumb color was affected significantly $(\mathrm{P}<0.05)$ and crust color non-significantly $(\mathrm{P}>0.05)$. The mean values for sensory parameters of various treatments have been presented in Table 8. Fermentation process improves the sensory attributes of the product. It results in the product with increased volume and good texture. The primary and secondary metabolites produced during the fermentation process have positive effects on the sensory and textural properties of bread. The organic acids (acetic and lactic acids) produced by lactobacilli greatly affect the rheological properties of sourdoughs such as the dough gas retention and elasticity of gluten network. Bread flavor is one of the key factors for consumer acceptance. The sensory scores regarding the flavor of sourdough bread have the higher value than that of yeast leavened breads, resulting in the improved flavor of the bread. It may be due to the addition of sourdough in the bread production (Arendt et al., 2007).

Conclusion: The cultivars used for sourdough production were subjected to different physicochemical tests. The cultivar, Millat-2011 showed the highest thousand kernel and test weights as well as wet gluten content, pelshenke and SDS sedimentation value. Among the proximate composition and farinographic characteristics, Millat-2011 had the highest crude protein, water absorption, tolerance index and softening of the dough. The sourdough breads prepared from mixed culture showed the improved amino acid and flavor profile of the product. The use of mixed culture in bread production would result in the product with better quality in terms of nutritional, functional and sensory characteristics. Thus the sourdough bread prepared from mixed culture and Millat-2011 was awarded the highest scores for sensory characteristics in terms of quality and overall acceptability.

\section{REFERENCES}

AACC. 2006. Approved Methods of American Association of Cereal Chemists. Am. Assoc. Cereal Chem. Inc. St. Paul MN.

Ahmad, I., F.M. Anjum and M.S. Butt. 2001. Quality characteristics of wheat varieties grown in Pakistan from 1933-1996. Pak. J. Food Sci. 11: 1-4.

Anjum, F.M. and C.E. Walker. 1991. A review on the significance of starch and protein to wheat kernel hardness. J. Sci. Food Agric. 56: 1-13.

Anjum, F.M. and C.E. Walker. 2000. Grain, flour and bread making properties of eight Pakistani hard white spring wheat cultivars grown at three different locations for 2 years. Int. J. Food Sci. Technol. 35: 407-416.
Arendt, E.K., L.A.M. Ryan and F. Dal Bello. 2007. Impact of sourdough on the texture of bread. Food Microbiol. 24: $165-174$.

Banu, L., I. Vasilean and I. Aprodu. 2011. Quality evaluation of the sourdough rye breads. Food Technol. 35: 94-105.

Barber, S. and R. Baquean. 1989. Microflora of the sourdough of wheat flour bread. XI. Changes during fermentation in the microflora of sourdoughs prepared by a multi-stage process and of bread doughs thereof. Rev. Agro. Tecnol. Alim. 29: 478-491.

Dabbour, I.R. and H.R. Takuri. 2000. Protein digestibility using corrected amino acid score method (PDCAAS) of four types of mushrooms grown in Jordan. Plant Food Human Nutr. 57: 13-24.

Gobbetti, M., M.S. Simonetti, A. Corsetti, F. Santinelli, J. Rossi and P. Damiani. 1995. Volatile compound and organic acid productions by mixed wheat sour dough starters: influence of fermentation parameters and dynamics during baking. Food Microbiol. 12: 497-507.

GOP (Government of Pakistan). 2013. Agricultural Statistics of Pakistan. Ministry of Food, Agriculture and Cooperatives. Food and Agriculture Division, Economic Wing, Islamabad, Pakistan.

Hansen, A., B. Lund and M.J. Lewis. 1989. Flavor of sourdough rye bread crumb. Food Sci. Technol. 22: 141-144.

Kam, W.Y., W.M. Wan Aida, A.M. Sahilah and M.Y. Maskat. 2011. Volatile compounds and lactic acid bacteria in spontaneous fermented sourdough. Sains Malaysiana 40: 135-139.

Khan, I. and A. Zeb. 2007. Nutritional composition of Pakistani wheat varieties. J. Zhejiang Univ. Sci. 8: 555559.

Khan, K. and P.R. Shewry. 2009. Carbohydrates. In: Y. Pomeranz (ed.), Wheat Chemistry and Technology, $4^{\text {th }}$ Ed. St. Paul MN, USA.

Land, D.G. and R. Shepherd. 1988. Scaling and ranking methods. In: J.R. Piggott (ed.), Sensory Analysis of Foods. Elsevier Appl. Sci. London. pp.155-185.

Lefebvre, D., V. Gabriel, Y. Vayssier and C. FontagneFaucher. 2002. Simultaneous HPLC determination of sugars, organic acids and ethanol in sourdough process. LWT. Food Sci. Technol. 35: 407-414.

Liljeberg, H., C. Lonner and I. Bjorck. 1995. Sourdough fermentation or addition of organic acids or corresponding salts to bread improves nutritional properties of starch in healthy humans. J. Nutr. 125: 1503-1511.

Nielsen, M.M., M.L. Damstrup, A. Dal Thomsen, S.K. Rasmussen and A. Hansen. 2007. Phytase activity and degradation of phytic acid during rye bread making. Eur. Food Res. Technol. 225: 173-181. 
Ostman, E. 2003. Fermentation as a means of optimizing the glycemic index-food mechanisms and metabolic merits with emphasis on lactic acid in cereal products. PhD thesis, Department of Applied Nutrition and Food Chemistry, Lund University, Denmark.

Pasha, I., F.M. Anjum, M.S. Butt and J.I. Sultan. 2007. Gluten quality prediction and correlation studies in spring wheats. J. Food Qual. 30: 438-449.

Pasha, I., Q.A.B. Khan, M.S. Butt and M. Saeed. 2013. Rheological and functional properties of pumpkin wheat composite flour. Pak. J. Food Sci. 23: 100-104.

Pedersen, B., M. Hansen, L. Munck and B.O. Eggum. 2004. Weaning foods with improved energy and nutrient density prepared from germinated cereals: 2. Nutritional evaluation of gruels based on barley. Food Nutr. Bull. 11: 46-52.

Poutanen, K., L. Flander and K. Katina. 2009. Sourdough and cereal fermentation in a nutritional perspective. Food Microbiol. 26: 693-699.

Rehman, S. and J.A. Awan J.A. 2011. Flavor of bread and bakery products. In: H. Jelen (ed.), Food Flavor; Chemical, Sensory and Technological Properties. CRC Press, Taylor and Francis Group. pp.301-330.

Rehman, S., J.A. Awan, F.M. Anjum and A. Randhawa. 2014. Antinutrients and toxicity in plant based foods: cereals and pulses. In: R. Bhat and V.M. Gomez-Lopez (eds.), Practical Food Safety Contemporary Issues and Future Directions. John Wiley and Sons LTD, West Sussex, UK. pp.311-330.

Robert, H., V. Gabriel, D. Lefebvre, P. Rabier, Y. Vayssier and C. Fontagne- Faucher. 2005. Study of the behavior of Lactobacillus plantarum and Leuconostoc starters during a complete wheat sourdough bread making process. LWT-Food Sci. Technol. 39: 256-265.

Safdar, M.N., N. Siddiqui, A. Mumtaz, M.A.S. Raza and Z. Khan. 2012. Comparison of new wheat varieties grown in Punjab for biscuit production. Sarhad J. Agric. 28: 215-221.

Sandra, G., C. Schwab, F. DalBello, A. Coffey, M. Ganzie and E. Arendt. 2012. Comparison of the impact of dextran and neuteran on the quality of wheat sourdough bread. J. Cereal Sci. 56: 531-537.

Spicher, G. and E. Rabe. 1981. Die micrroflora des sauerteiges. XII. Mitt: Der Einfluss der temperature auf die Lactat-/Acatat-bildung in mit homofermentative Milchaurebakterien angestellten Sauerteigen. Z. Lebemsm. Unters. Forch. 172: 20-25.

Spicher, G., E. Rabe, R. Sommer and H. Stephan. 1982. Communication on the behaviour of heterofermentative sourdough bacteria and yeasts in mixed culture. Z . Lebensm. Unters. Forsch. 174: 222-227

Steel, R.G.D., J.H. Torrie and D. Dickey. 1997. Principles and Procedures of Statistics: A biometrical approach, $3^{\text {rd }}$ Ed. McGraw Hill Book Co. Inc. New York.

Thiele, C., M.G. Ganzle and R.F. Vogel. 2002. Contribution of sourdough lactobacilli, yeast and cereal enzymes to the generation of amino acids in dough relevant for bread flavor. Cereal Chem. 79: 45-51.

Vernocchi, P., S. Valmorri, V. Gatto, S. Torriani, A. Glanotti and G. Suzzi. 2004. A survey on yeast microbiota associated with an Italian traditional sweet-leavened baked good fermentation. Food Res. Int. 37: 469-476. 